\title{
Social Policy
}

\author{
An Introduction \\ RICHARD M. TITMUSS
}

Edited by Brian Abel-Smith and Kay Titmuss

This book, an edited version of the introductory lectures on social policy which the late Professor Titmuss gave at the London School of Economics, is an introduction only in the sense that it illustrates the immense complexity of defining such commonly used terms as 'Social Services', 'Social Welfare' and the 'Welfare State', and the difficulty of separating social policy from economic policy. Professor Titmuss describes the wide range of social, medical and economic changes in society which generate social problems, and analyses the implications of different solutions. He demonstrates the limitations of the courts and private insurance as mechanisms for meeting social needs and poses the value choices between mass government and mass market, equity and equality, altruism and egoism.

'This book consists of the edited notes of a series of introductory lectures given at LSE and last delivered in the early months of 1973 ... For connoisseurs they contain many examples of his (Professor Titmuss') deft turn of phrase and rich sense of paradox. The lectures reveal the undiminished critical independence of his mind...'

\section{The Guardian}

'The publication of Richard Titmuss's last series of introductory lectures on social policy is a fitting tribute to the memory of a teacher of genius.'

New Society

Ł3.50, Paperback $£ 1.30$

\section{GEORGE ALLEN \& UNWIN LTD.,}

Park Lane, Hemel Hempstead, Herts. HP2 4TE. 


\title{
Martin Robertson B Company Ltd
}

\author{
LAW AND STATE: The Case of Northern Ireland \\ Law in Society Series \\ Kevin Boyle, Lecturer in Law, Tom Hadden, Part Time Lecturer in Law, \\ Queen's University, Belfast, and Paddy Hillyard, Lecturer in Social \\ Administration, New University of Ulster.
}

This book is based on the submission to the Gardiner Committee made by the authors. It shows how the army has misused the system in pursuit of its own 'military security' policy, based on a large scale screening in Republican areas, and how this results in different rules being applied to Protestant and Catholic suspects.

April 208 pages $£ 2.25$ paper $£ 4.75$ boards

\section{THE EUROPEAN COMMUNITIES}

Volume 1-Social Policy of the European Coal and Steel Community 1951-1970

Volume 2-Social Policy of the European Economic Community 1958-1972 Doreen Collins, Senior Lecturer in Social Policy, University of Leeds The aim of this work is to provide a record of the implementation of the social clauses of the treaties which created the Coal and Steel Community and the European Economic Community, and to discuss the implications of this history in terms of the general development of the Communities.

July Volume I 144 pages c. $€ 3.95$ boards Volume 2320 pages c. $€ 5.95$ boards

\section{THE POVERTY OF EDUCATION}

David Byrne, Research Director, Tynemouth Community Development Project, Bill Williamson, Lecturer in Sociology, and Barbara Fletcher, Department of Sociology and Social Administration, University of Durham.

The results of a research project which examined variations in the educational attainment of children from different social classes and regional backgrounds.

January 224 pages $€ 4.95$ boards

\section{ECONOMIC POLICIES AND SOCIAL GOALS: Aspects of Public Choice}

York Studies in Economics

Edited by A. J. Culyer, Senior Lecturer in Economics and Assistant Director, Institute of Social and Economic Research, University of York. This is the first book in the York Studies in Economics series edited by Professor Alan Peacock and Professor Jack Wiseman. It presents a set of original essays on substantive problems in social and economic policy by York economists.

December 1974348 pages $\quad$ \&8.25 boards

\section{THE ECONOMICS OF SOCIAL POLICY}

\section{A. J. Culyer}

'This is an extremely useful textbook, which fills a gap in the literature and will undoubtably be used most successfully in higher education,' Professor Maurice Peston, New Society.

1973280 pages $€ 2.25$ paper, $€ 4.50$ boards

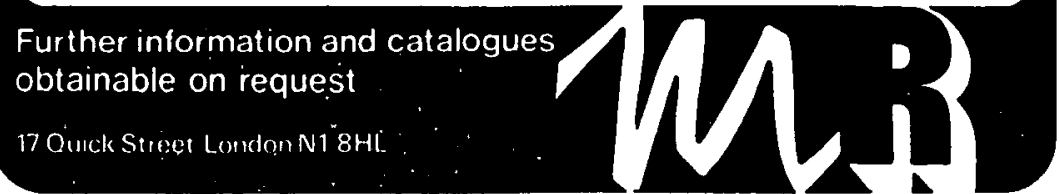




\section{Journal of Social Policy}

\section{NOTES FOR CONTRIBUTORS}

1. All contributions and correspondence should be sent to: The Editor, Journal of Social Policy. The London School of Economics and Political Science, Houghton Street, Aldwych, London wC2A 2AE. All books for review should be sent to: The Review Editor, Journal of Social Policy, Department of Sociology and Psychology, Chelsea College, University of London, Manresa Road, London SW3 6LX.

2. Articles should generally contain between 5,000 and 10,000 words including footnotes, although longer or shorter articles may be accepted by arrangement with the Editor. Short articles stand a better chance of early publication.

3. Submission of an article is taken to imply that it has not previously been published, or is not being considered for publication elsewhere. If an author is publishing a related article elsewhere, this fact should be stated.

4. Contributions (articles, review articles, reviews) should be clearly typed on one side of the paper only using a conventional size of paper, preferably A4. All material should be typed double-spaced with generous margins. Contributors should send two copies and keep one copy of the typescript for correcting proofs.

5. Contributions should be accompanied by an abstract of between one and two hundred words.

6. References to books and articles should include the following details: in the case of books, the full title and author or authors, place of publication, publisher and date; in the case of articles, the title and author or authors, full name of the journal, volume, year and page reference (first and last page). References and other footnotes should be numbered consecutively throughout and typed separately at the end of the article. Good articles which contain this bibliographical information will be accepted, even if they do not follow the journal's own arrangement of the information.

7. Tables should be clearly laid out and designed to fit on to a page $91 \times 61$ inches. Vertical lines between columns should be omitted, and horizontal lines limited to the top and bottom of the table, with an additional one below the column headings. Totals and percentages should be labelled, and units identified.

8. Contributors are advised to look through earlier issues of the journal for guidance on points of general style.

9. First proofs may be read and corrected by contributors provided that they can give the editor an address through which they can be reached without delay and can guarantee to return the corrected proofs to the editor, by airmail where appropriate, within ten days of receiving them. The master proof will always be sent direct to the editor by the printer; contributors will receive duplicates.

10. Authors of articles and review articles (but not book reviews) receive twentyfive free offprints. Additional copies may be bought if ordered at proof stage.

11. Contributors of accepted articles will be asked to assign their copyright, on certain conditions, to Cambridge University Press, to help protect their material, particularly in the USA.

Cambridge University Press

Bentley House, 200 Euston Road, London NW1 2DB

American Branch : 32 East 57th Street, New York, N.Y. 10022

Single parts $£ 3.00$ net (US $\$ 9.00$ in USA and Canada)

1975 Annual subscription $\$ 10.00$ net (US \$30.00 in USA and Canada)

Printed in Great Britain by

Western Printing Services Ltd. Bristol 
TABLE OF CONTENTS

\section{ARTICLES}

Barbara N. Rodgers: Family Policy in France

BARBARA ADAMS with JUDITH OKELY, DAVID MORGAN and DAVID

SMITH: Gypsies: Current Policies and Practices

ALAN MAYNARD and RACHel TINGle: The Objectives and Performance of the Mental Health Services in England and Wales in the 1960s

REVIEW ARTICLE

MERVYN A. MURCH: One-parent Families

KATHLeen M. Slack: Social Administration Digest

\section{BOOK REVIEWS}

S. N. DU BEY : Administration of Social Welfare Programmes in India (V. Jagannadham)

PAMela ROBy (ed.): Child Care-Who Cares? (Jean Packman)

TESSA BLACKSTONE: Education and Day Care for Young Children in

Need: The American Experience (Sonia Jackson)

KA THLEEN JONES (ed.): The Year Book of Social Policy in Britain 1972 (Miriam E. David)

P. H. J. H. GOSDEN: Self-Help: Voluntary Associations in the Nineteenth Century (José Harris)

MICHAEL A. SMITH, STANLEY PARKER and CYRIL S. SMITH (eds):

Leisure and Society in Britain (Noel Parry)

RALPH ROWBOTtom et al.: Hospital Organization: A Progress Report on the Brunel Health Services Organization Project (Rosemary Stewart) ENID HUWS JONES: Mrs Humphry Ward (Jean L'Esperance) ENID BALINT and J. S. NORELl (eds): Six Minutes for the Patient

(David Robinson)

ANDREW RIGBY: Alternative Realities: A Study of Communes and their Members (Philip Priestley)

PHILIP BEAN: The Social Control of Drugs (John R. Cypher)

DOROTHY WEDDER BURN (ed.): Poverty, Inequality and Class Structure (Gordon Rose)

GEORGE BARON and D. A. HOWELL: The Government and Management of Schools (Maurice Kogan)

Michael H. COOPER (ed.): Social Policy: A Survey of Recent Developments (Paul Wilding)

BRIAN BARRY: The Liberal Theory of Justice: A Critical Examination of the Principal Doctrines in A Theory of Justice by John Rawls (R. S. Downie)

VICTOR GEORGE: Social Security and Society (Frances Fox Piven)

ANDREW DUNSIRE: Administration: The Word and the Science (Adrian L. Webb)

STEPHEN CASTLES and GODULA KOSACK: Immigrant Workers and

Class Structure in Western Europe (Robin Oakley)

WILliAM TAYLOR (ed.): Research Perspectives in Education (Dudley

Plunkett)

RAYMOND PLANT: Community and Ideology (Colin Bell) 